\title{
Socio-economic requirements as a fundament of innovation in food packaging
}

\section{Agnieszka Cholewa-Wójcik ${ }^{1}$ (D), Agnieszka Kawecka² (D),}

\section{Carlo Ingrao ${ }^{3}$ (D), Valentina Siracusa ${ }^{4}$}

\begin{abstract}
The food packaging industry trends reflect the identified needs and requirements of consumers because entrepreneurs should satisfy changing consumer requirements to achieve and maintain a competitive advantage due to innovation. In the group of socio-economic needs, the most important ones are lifestyle changes, improving the quality of life through the added value offered to consumers through packaged products, profitable companies in the sector, packaged product safety and environmental protection. The main aim of the study was exploring the validity of food packaging requirements concerning the satisfaction of consumer needs. The resulting hierarchy of important needs and requirements represents the foundation for solutions and strategies to improve the quality of a consumer's life. Analysis of the results clearly shows that among all socio-economic needs and requirements posed to food packaging, safety is the most critical need for consumers. Other packaging properties such as convenience and legal requirements fulfillment are important. Proposed model packaging, which will stratify consumers' needs and requirements and will help to improve their quality of life, should be characterized by health, simplicity, identity, aesthetics, and meaning. The packaging industry is a branch considered to have high potential in the field of applying innovative solutions. This is mainly related to the desire of introducing solutions in the areas of improving safety, functionality, communication and environmental protection. Identification and understanding of consumer needs is a valuable source of information useful

\footnotetext{
1 Agnieszka Cholewa-Wójcik, Ph.D., Associate Professor, University of Economics, Department of Product Packaging, Rakowicka 27 St., 31-510 Cracow, Poland, e-mail: cholewaa@uek.krakow.pl (ORCID ID: 0000-0001-5081-1416).

2 Agnieszka Kawecka, Ph.D., Associate Professor, University of Economics, Department of Product Packaging, Rakowicka 27 St., 31-510 Cracow, Poland, e-mail: kaweckaa@uek.krakow.pl (ORCID ID: 0000-0001-6895-6613).

3 Carlo Ingrao, Ph.D., Associate Professor, Kore University of Enna, Faculty of Engineering and Architecture, Cittadella Universtiaria, Enna Bassa, 94100, Enna, Italy, e-mail: carlo.ingrao@unikore.it (ORCID ID: 0000-0002-3359-2458

4 Valentina Siracusa, Ph.D., Associate Professor, University of Catania, Department of Chemical Sciences, Viale Andrea Doria, 6, Catania, Italy, e-mail: vsiracus@dmfci.unict.it, (ORCID ID: 000-0001-9055-5082).
}

Received 3 April 2018; Revised 11 September 2018, 24 September 2018, 13 February 2019; Accepted 26 February 2019 
when developing improvements. Proposed components of model packaging follow the motto of the World Packaging Organization, which says: "Better quality of life through better packaging."

Keywords: food packaging, socio-economics needs, guidelines of innovation in food packaging.

\section{INTRODUCTION}

Innovation is an important element for both the development and the competitive advantage of packaging systems, especially for those utilized in the food supply chain. Innovations are conditioned by many factors of a very diverse nature that stimulate or limit them. Innovations depend to a large extent on the quantitative and qualitative transformations taking place in consumer behavior - the largest and most important group of clients in the trade. Those innovations are determined by many factors. By reviewing the current specialized techno-scientific literature, and analyzing the international industrial association elaborations, those factors can be grouped into the following main categories: business dynamics, distribution, regulation and consumption (The Future...2013). In particular, the business dynamics factors influence the packaging industry and, in turn, lead to increasing the requirements for brand enhancement/differentiation, in a progressively more competitive context that also includes the development of new innovative packaging materials. In the field of product distribution, and so among the related factors, important roles are played by: the consolidation and globalization rates of the retailers involved; the technological quality and innovation of the supply chains; and e-commerce. Moreover, very important drivers for industrial development are the current legal regulations that concern:

- the protection of consumer interests in terms of safety, protection of consumer economic interests; and

- the adoption of new regulatory requirements related to the recycling of packages, as well as the reduction in carbon footprint associated with their life cycles and, as a result, the impact on global climate change (Position Paper - Market Trends and Developments, 2008). In this regard, it should be observed that a huge number of researchers have assessed the environmental issues related to the food packaging field such as, just to name a few, Ingrao et al. (2015 a,b), Siracusa et al. (2014), and Gironi and Piemonte (2010). Those authors investigated different food packaging products (i.e. films, trays, bottles and clamshells) to assess the potential environmental improvements resulting from innovative solutions like the reduction of the input virgin polymer utilized, as well as the usage of recycled and/or natural polymers. 
Results from the analysis of the aforementioned factors contributed to formulating the statement that nowadays packaging is supposed to perform well according to the following three dimensions: profit (economy aspect); planet (environmental aspect); and people (social aspects) (Yam, 2009). Social aspects should also be accounted for in the planning of marketing strategies for product and packaging.

However, it should be underscored that the socio-economic needs and expectations of consumers are acknowledged as mostly stimulating industrial development. In this context, the major consumption trends are depicted in Figure 1.

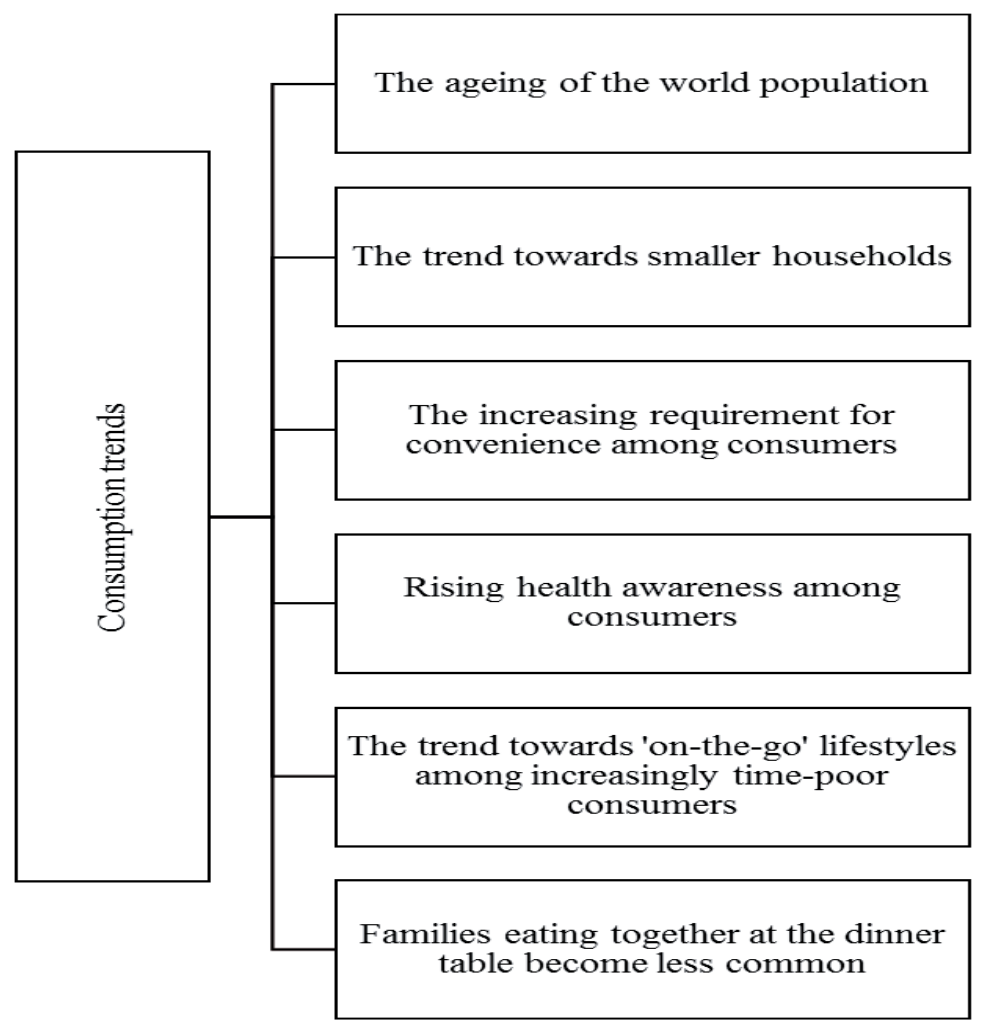

Figure 1. Consumption trends in the food market

Source: self-elaboration based on Position Paper - Market Trends and Developments (2008).

Social trends have a significant impact on the consumer goods market, and thus on the goods offered in it. Among the directions significantly affecting the changes taking place in the packaging market, we should mention first of all the following (Emblem \& Emblem, 2011): 
- the aging of society;

- the change in the structure of households;

- the changes in lifestyle;

- the increase in the requirements for the convenience of use of products;

- the rising health awareness.

The aging of society is a phenomenon that has been much more intense in recent decades. Especially in more developed countries, the dynamics of its growth accompanied by a drop in the birth rate has caused the percentage of older people in society to grow rapidly. Thus, the aging process has not only a demographic dimension but also an economic and social dimension.

Population aging is an occurrence which during the past several decades has expressively expanded. It has been easy to see the growing proportion of old people in society. It results from the greater longevity of people, the progress of civilization and a higher quality of life. More factors, such as a family model being promoted, the level of wealth of society, the level of social health care, the number of women who are active in the labour market, the educational level of the population and a social policy adopted by a state, exert a direct impact on the phenomenon of population ageing, (Irvine, 2008).

In Poland, the process of society aging has been seen since the 1990s. In 1990 , people aged 60 and over accounted for $12.8 \%$ of the whole population, whilst in 2013 it was $21.5 \%$. It is projected that this share of people 60 years and older will be $29 \%$ in 2030 and $40.4 \%$ in 2050 (according to information given by GUS - the Central Statistical Office of Poland in 2016). At the same time, it is predicted that the population will grow by 5.4 million by 2050 . A significant increase in the number of older people is already signaled in the first years of the forecast because the population of older people will be fed by very large numbers of births from the 50 s and 60 s of the last century. The course of changes in the number of subpopulations at the age of 60 years and more coincides with the occurrence of highs and births in the second half of the last century (Raport na temat wpływu..., 2016).

An expression of this are changes in the consumption structure and an increased demand for products (including packaging) adapted to the needs of older consumers. Therefore, this situation forces the producers of products and their packaging to adapt activities to the changing environmental conditions. Especially important solutions are easy opening packaging in smaller sizes with an appropriate typeface and font size to ensure the visibility of the text (Emblem \& Emblem 2011).

Another change affecting the transformation of the packaging industry is the change in the structure of households. When assigning the attribute of an economic operator to a household, it should be noted that its activity is 
focused primarily on satisfying individual and common consumption needs. This essential household goal is the basis for decisions related to the selection of products that are able to meet their needs and requirements. The scope and structure of needs met in households is shaped both by external factors (e.g., prices and supply of goods) as well as internal ones resulting from the socio-demographic and economic structure of households and their members. In addition to the above-described factors of an objective nature affecting consumer consumption decisions, also subjective determinants should be added (so-called sociological and psychological factors) (Zalega, 2007).

What is more, the structure of households is changing as there is a systematic decrease in the number of household members. In 2002 the average number of people in the home-based economy was 2.84 , while in 2011 this number was 2.82, and in 2014 it declined further to 2.73. The forecast for 2030 predicts a drop to 2.40 people in the household. According to the forecasted results for the population in the years 2014-2050, the structure of people by age will undergo dynamic changes, being a consequence of the demographic "wave." Taking into account the decreasing number of births and the rapid aging of Polish society, this situation will be reflected in the forecast of the structure of households (Prognoza gospodarstw domowych..., 2016).

Another important trend affecting the food market is the so-called "convenience foods." This trend refers to food products that, thanks to the use of appropriate technologies and raw materials in the production, show the desired durability but also allow quick preparation, either by themselves or in combination with other ingredients of ready-to-eat meals. This category includes products such as: ready for processing, pre-prepared for culinary works, ready for thermal processing, heating, consumption and table serving. Hence the popularity of ready soups, meats, frozen foods, salads and, finally, fruit and vegetable cocktails and other beverages. Consumers expect fast and easily prepared products without the need to unpack them (Tarczyńska, 2013). Thus, the role of packaging containing portions of meals adapted to individual needs, in which there is the possibility of heating a meal or selfheating packaging, significantly increases. Another need for the modern consumer is the convenience and functionality of using the packaged product. The improvement of convenience and functionality is possible by designing innovative packaging construction solutions. The convenience of use can be analyzed bi-directionally. On the one hand, it is related to the ergonomics of packaging, taking into account the shape of the packaging that facilitates the grip and use of the product, the method of opening, portioning, closing and dispensing the product. On the other hand, the convenience of use is related to the marketing of convenient packaging, for example for heating 
in microwave ovens or packaging in which a simple exothermic reaction is followed by heating the product packed in it (Sykut et al. 2013).

An important stimulus for the development of the packaging industry is also a trend associated with a change in lifestyle, which influences the increase in demand for packaging that facilitates the use. This caused, among other things, an increase in the demand for products packed in convenient packaging. In addition, consumers desire packaging with innovative solutions in the field of improvements regarding the method of opening, closing, dispensing and handling the packed product and protection against unwanted opening (Lisińska \& Kuśnierz, 2011).

In addition to demographic changes, consumer needs resulting from demographic change have a significant impact on innovation development. As a result, the packaging optimization trend is marked. Instead of the recently popular packaging with large capacities, packaging is becoming more and more dominant with a size suited to the needs of small families, people aging or running a household independently. The packaging should be user-friendly, enabling multiple opening and closing, easy transport from the place of purchase and convenient storage at home. Currently, consumers often expect personalized packaging, printed "on demand" by digital printing. Personalization introduces an element of interaction between a consumer and a given brand. The development of interaction is also augmented reality. The consumer can, using a smartphone, connect the actual image of the product with an artificially generated animation, offering additional information about the product, e.g. language versions, preparation proposals or a multimedia game. Consumer awareness will be transferred from the product to the service.

Social trends affecting consumption are closely related to the cycle of purchasing behaviors defined as a set of actions and activities aimed at satisfying the consumer's own needs. In this cycle, the consumer's action begins to feel the need (understood as a state of feeling of absence), while having preferences regarding the object that can satisfy these needs. In order to satisfy them, the consumer undertakes actions, consisting, among others, in searching for an object that is able to satisfy the need, often looking for information about objects and evaluating available solutions by making a choice and making a purchase. The consumption process also carries out the analysis of the choice made, the assessment of the degree of satisfaction of the need according to the preferences. It is assessed by the level of customer satisfaction and the likelihood of resuming the purchase of a consumed product or alternative objects (Rudnicki, 2012).

The food market, both in Poland and in the world, is one of the most innovative segments, although moderate consumer interest in new food 
products does not lead to particular activity in this area. At the same time, there is an increase in consumer awareness of the relationship between food, diet and health, which for many food companies may be a prerequisite for the marketing of products with specific pro-health, functional or enhanced nutritional properties. Such trends, in relation to the domestic food market, may also be justified by the fact that health is the dominant value for the vast majority of Poles (Dąbrowska et al. 2013), and consumers are asked what is particularly important for them in food, most of them they answer "not to contain ingredients that harm me" and "to affect good health" (95\% and $94 \%$ respectively think that these are important and very important attributes of food). This image only distorts the fact that the research cited shows that consumers value the taste of food more than health attributes. This situation is confirmed by global trends. In recent years, both in Poland and in the world, there are many new trends in consumer behavior towards food, which among others relate to health understood as perceiving food in terms of a positive impact on health (Gutkowska et al., 2014).

In conclusion, consumers are undoubtedly an important source of innovation in the retail trade. Their ideas can inspire entrepreneurs to seek new solutions, introduce radical changes. Sometimes, however, paying too much attention to the expectations and proposals of customers may contribute to the inhibition of the innovation process. The reason may be the reluctance of clients to change (especially new solutions), a misunderstanding of technical novelties, or the inability of clients to imagine what these new solutions may be and what their benefits may be. For the development of innovations, it is particularly important to observe consumer behavior, which is affected by changes constantly occurring in the environment of consumers. Changes in the environment contribute to the emergence of new trends in consumer behavior and thus create new conditions for making decisions and actions in the area of purchase (10 Trends..., 2011).

The study discussed in this paper was aimed at exploring the validity of food packaging requirements with a view to the satisfaction of consumer needs. Furthermore, the importance of giving hierarchy to those requirements can represent the foundation for the implementation of technological solutions and strategies enabling global improvement and innovation in the food packaging sector. As a result, there would be enhancement of the quality of people's lives and, in turn, of entire societies worldwide.

Finally, the authors believe that the results obtained might contribute to enriching the international knowledge in the food packaging field, and support stakeholders to find, develop and promote those solutions and strategies. 


\section{LITERATURE BACKGROUND}

Market trends reflect the identified needs and requirements of consumers: this is because entrepreneurs should satisfy continuously changing market requirements to achieve and maintain a competitive advantage. In the group of socio-economic needs, the most important ones are: lifestyle changes oriented to improving the quality of life through the added value offered to consumers through packaged products; enhancement of the income for the companies operating in the sector; and packaged product safety and environmental protection (Capitanio, Coppola, \& Pascucci, 2009; Loizou, Michailidis, \& Chatzitheodoridis, 2013).

The rapid development of the food packaging industry and the forecasts for increased demand for modern and innovative packaging solutions have made it important to analyze both needs and demands of consumers for food packaging. Packaging systems are highly important for the protection of food quality and shelf life, as they are designed to allow consumers to obtain foods that correspond to their quality and safety expectations, also after traveling for long distances (Ingrao et al., 2015a). Therefore, it can be asserted that the package is an important element that shapes the quality of life and, therefore, due attention should be paid to the satisfaction of those needs. This can be done through the dynamic development of the packaging industry and through enhanced variety and sophistication of packages launched on the market (Lisińska-Kuśnierz \& Ucherek, 2011, Ahmadi, Bahrami, \& Ahani, 2013).

The problem of consumer expectations related to the packaging of selected product groups available in the market has previously been addressed by several author teams in their research studies. Perception of food quality through the prism of packaging was undertaken by several author teams such as, for instance, Chaya and Hort (2013), Labbe et al. (2013), Carrillo et al. (2014), Fiszman et al. (2015). In their studies, they identified features and properties of a packaging's visual layer that influence consumer perception of the overall quality of the product. The influence of packaging elements on a purchasing decision was investigated by authors like Butkevičienè, et al. (2008), Estiri et al. (2010), and Mueller and Szolnoki (2010), while the issues of consumer behaviors in relation to packaging were studied by Solomon et al. (2010), and Kawecka (2015), Lisińska-Kuśnierz and Kabaja (2018). Other research concerning the analysis of consumers' opinions, needs and requirements on several product groups was developed by Lisińska-Kuśnierz and Ucherek (2011), Rebollar et al. (2012), Lisińską-Kuśnierz (2014), Svanes et al. (2014), and Cholewa-Wójcik (2014, 2015).

It should be observed that results from the research mentioned above refer to selected packaging features related to the social aspect of packaging 
like visual aspects, communication and functionality. As a matter of fact, those studies were focused upon investigating the ways consumers make decisions on what type of food to buy, based upon the appeal and the information reported in the package. In this context, the in-depth analysis of those studies formed the basis for investigating the specialized literature related to the role of packaging in consumer behavior. Moreover, it highlighted a lack of research and full analyses with regard to the merits of consumer expectations towards food packaging in the realization of their needs and requirements.

Among the trends influencing the development of the food packaging industry, consumption can be considered as the most important one. According to The Future of Global Packaging to 2018 consumption of food products, as the main factor of industrial development is closely related to social needs (The Future..., 2013). These needs are expressed as both requirements and expectations of consumers for food products packaging. Social needs are connected with (Food and Beverage Packaging Technology, 2011):

- packaging quality properly chosen for the product;

- communication with consumers;

- convenience and functionality;

- extension of shelf-life by innovative systems of packing and storage without chemical preservative;

- safety;

- environmental-friendliness.

When the overall quality of a package is adjusted to the food content, it becomes an important element for protection and preservation of the quality of that food. Furthermore, hygiene is also important to be considered in the design of a package, as it is strictly linked to the social need for safety.

Communication with consumers through packaging is related to the presence of proper information and graphic signs (pictograms) that should be placed in a readable, legible way and is easily found by the consumer.

Convenience is connected with special equipment or elements improving utilization of a package. Improvements can be made in the ability to repeatedly open and close the package; in shaping the package to be ergonomic, so as to ease its grip and manipulation. The latter can be improved also by giving proper dimensions and mass not to the package but also to the food content, so to facilitate manipulation of the packed food in its whole. Functionality represents one of the added values for packaging systems, because it facilitates and improves their usage, above all for special groups of consumers (i.e., children, seniors and persons with physical disabilities), and increases their ergonomic-related issues.

Extension of shelf-life by means of innovative systems of food packing and storage without chemical preservative is also connected with lifestyle: 
it is important because of changes in shopping patterns. Shopping is made rarely, and food must be kept unchanged for a longer time. On the other hand, using chemical preservatives is not well seen by social groups promoting the awareness and purchase of healthy and safe foods.

Moreover, environmental awareness worldwide is increasingly leading people to demand food packaging solutions whose production has involved consumption of: less non-renewable fuels and energy; less raw materials; and/or, when possible, more recycled materials. Moreover, packages are more and more developed and produced so that they can be easily re-used and recycled into new materials for other industrial applications, so reducing the impacts in their life cycles (Lisińska-Kuśnierz \& Ucherek 2011). For this reason, they are manufactured by assembling different materials, like paper and plastics, in ways that they can be easily separated and recycled.

Referring to the concept proposed by Bix et al. (2009), packaging functions (protection, utility and communication) are realized in three surroundings such as physical, environment and humans. Detailed analyses of packaging functions allow the development of a matrix in which every component is associated with packaging properties and specific elements as referred to consumers' needs. Taking into consideration that social needs are closely correlated with consumer requirements regarding packaging, a summary of those needs/requirements related to human lifestyles is presented in Table 1.

Table 1. Requirements to food product packaging from a consumer point of view

\begin{tabular}{ll}
\hline $\begin{array}{l}\text { Requirements } \\
\text { groups }\end{array}$ & Specific consumers' requirements concerning food packaging \\
\hline & $\begin{array}{l}\text { Protection of both quantity and quality of the contents of the vari- } \\
\text { ous conditions of use } \\
\text { Variety of packaging materials }\end{array}$ \\
& Variety of packaging shapes and construction forms \\
Lifestyle & Convenience \\
& Packaging/labels informativity \\
& Aesthetics \\
& Packaging resistance on exposures \\
& Price \\
\hline
\end{tabular}




\begin{tabular}{|c|c|}
\hline $\begin{array}{l}\text { Requirements } \\
\text { groups }\end{array}$ & Specific consumers' requirements concerning food packaging \\
\hline \multirow{10}{*}{ Added value } & Additional security guarantees in packaging \\
\hline & Variety of shapes and the volume of packaging \\
\hline & Packaging weight \\
\hline & Use of draining indicators \\
\hline & Variety of forms of joined manual \\
\hline & Type of packaging surface structure \\
\hline & Packaging transparency \\
\hline & Packaging design \\
\hline & $\begin{array}{l}\text { Information positioning manufacturer and product on the market } \\
\text { Indicators }\end{array}$ \\
\hline & Advertisement \\
\hline \multirow{7}{*}{ Safety } & Maintaining the amount and quality of content \\
\hline & Presence of first opening protection \\
\hline & Presence of security against unauthorized opening \\
\hline & Safety in use (no defects like sharp edges) \\
\hline & Safety when handling (e.g., when moving, stacking) \\
\hline & $\begin{array}{l}\text { No interactions between components of the packaging material } \\
\text { and the product }\end{array}$ \\
\hline & $\begin{array}{l}\text { Presence information affecting the safety of the user (i.e., the date } \\
\text { of minimum durability, warning about the presence of allergens) }\end{array}$ \\
\hline \multirow{4}{*}{$\begin{array}{l}\text { Legal regula- } \\
\text { tions }\end{array}$} & $\begin{array}{l}\text { Information concerning the protection of consumer interests in } \\
\text { terms of safety, protection of consumer economic interests and en- } \\
\text { vironmental protection }\end{array}$ \\
\hline & $\begin{array}{l}\text { Meeting the requirements of legislation, e.g., the integrity of the } \\
\text { product guarantee }\end{array}$ \\
\hline & warranty usefulness for different age groups of consumers \\
\hline & Information for adherence to laws related to packaging \\
\hline \multirow{7}{*}{$\begin{array}{l}\text { Environment } \\
\text { protection }\end{array}$} & $\begin{array}{l}\text { Type of packaging material from the point of load on the environ- } \\
\text { ment }\end{array}$ \\
\hline & $\begin{array}{l}\text { Homogeneity of the packaging material used in the manufacture } \\
\text { of the packaging }\end{array}$ \\
\hline & Use of recycled materials \\
\hline & Use of biodegradable materials \\
\hline & Minimized weight of packaging \\
\hline & Ease of recycling post-consumer packaging \\
\hline & Information on how to deal with the packaging after the utility \\
\hline
\end{tabular}




\section{RESEARCH METHODS}

A survey was conducted by this author team, to identify the needs and social requirements of consumers on food packaging. This also included planning a set of research tasks, as in the following list, to explore the validity of food packaging requirements concerning consumer needs:

- identifying the characteristics of packaging materials from the point of view of consumer expectations in relation to food packaging;

- determining the validity of the features and elements of food packaging systems from the point of view of consumers' needs and requirements;

- sociological determination of rank requirements in the field of food packaging.

The first step of this study was to determine in empirical ways, the expectations of consumers with regard to the requirements related to various aspects of the socio-economic needs. In the questionnaire, respondents gave answers on a verbal scale which, for analysis, was converted into a 6-point number scale. A 6-point grade scale was used $(0-$ no expiration, 1 - very little validity, 2 - little validity, 4 - average validity, 5 - high validity, 6 - very high validity) for the assessment of the importance of various characteristics of food packaging. Subsequently, from the converted respondents' answers, arithmetic average indications were calculated.

The survey was conducted from September to December in 2014 administering questionnaires (in traditional paper form) containing single, multiple choice and ordering questions. The survey was completed by 200 consumers of both genders and of varying ages and education levels, which was considered as a representative sample for the reliability of the survey itself and related results. The sample selection was randomly taken among clients of shopping malls in a city of over half million inhabitants in Poland's Malopolska region. The questionnaire was administered in a paper version and was filled in by a trained interviewer based on the answers given by the respondents. The form of an interview with questionnaire had been chosen because the interviews were conducted in shopping malls, for better group diversity (in comparison to internet surveys). A paper questionnaire without an interviewer was not possible in those conditions. That also helped respondents have a better understanding of each question and kept their interest. Also, there was no reason to reject any surveys due to a lack of answers. The socio-demographic profile realized, based upon the population sample interviewed, is presented in Table 2. 
Table 2. Socio-demographic profile of studied population

\begin{tabular}{lll}
\hline Socio-demographic criterion & Share [\%] \\
\hline Gender & Woman & 58 \\
Age & Man & 42 \\
& to 25 & 43 \\
& $26-35$ & 19 \\
& $36-45$ & 16 \\
& $46-55$ & 13 \\
Dwelling place & $56-65$ & 8 \\
& over 65 & 4 \\
& Countryside & 22 \\
& Town to 50 thous. & 9 \\
& $50-100$ thous. & 11 \\
Education & $100-250$ thous. & 5 \\
& $250-500$ thous. & 7 \\
& above 500 thous. & 46 \\
& Vocational & 12 \\
& Secondary & 38 \\
& Higher & 50 \\
\hline
\end{tabular}

Data surveyed were used to create the socio-demographic profile shown in Table 2 and then were elaborated and analyzed: the results obtained were discussed in the next sections. A rank-criteria-based analysis was carried out on the needs and requirements of consumers in the field of food packaging. Then, corrected sums of importance were calculated (element of $A B C D$ Suzuki method) and the averaged rank indicator for each group of needs/ requirements was determined accordingly. In order to eliminate answers to questions about the importance of particular concepts, and then to calculate a significant sum. Corrected sums of importance are sums of products of the number valid importance and the rank of cause.

Finally, the groups of analyzed socio-economic needs/requirements for food packaging were ordered based upon the designated indicator rank previously calculated.

\section{ANALYSIS AND RESULTS}

Results of the validity of food packaging features, calculated considering consumer requirements associated with separated groups of social needs as average scores, are presented in Table 3. 
Table 3. The validity of the features of food packaging regarding social needs

\begin{tabular}{|c|c|c|}
\hline \multicolumn{2}{|c|}{ Packaging features } & \multirow{2}{*}{$\begin{array}{l}\text { Features } \\
\text { validity } \\
\text { (pts.) } \\
4.2\end{array}$} \\
\hline \multirow{6}{*}{ 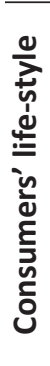 } & $\begin{array}{l}\text { Protection of the quantity and quality of the contents in various } \\
\text { conditions of use }\end{array}$ & \\
\hline & Packaging/labels informativity & 3.9 \\
\hline & Aesthetics & 3.7 \\
\hline & $\begin{array}{l}\text { The variety of packaging shapes and construction forms } \\
\text { Packaging resistance on exposures }\end{array}$ & $\begin{array}{l}3.6 \\
3.5\end{array}$ \\
\hline & Price & 3.3 \\
\hline & The variety of packaging materials & 3.2 \\
\hline \multirow{10}{*}{$\begin{array}{l}\frac{0}{2} \\
\frac{\pi}{20} \\
\frac{0}{0} \\
\frac{0}{0}\end{array}$} & Additional security guarantees in packaging & 3.8 \\
\hline & The variety of shapes and volume of packaging & 3.8 \\
\hline & Packaging weight & 3.7 \\
\hline & Packaging design & 3.7 \\
\hline & Indicators & 3.7 \\
\hline & Type of packaging surface structure & 3.7 \\
\hline & $\begin{array}{l}\text { The use of draining indicators } \\
\text { Packaging transparency }\end{array}$ & $\begin{array}{l}3.6 \\
3.6\end{array}$ \\
\hline & Advertisement & 2.9 \\
\hline & The variety of form of joined manual & 2.7 \\
\hline & Information positioning manufacturer and product on the market & 2.6 \\
\hline \multirow{7}{*}{ 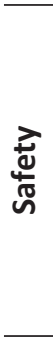 } & No interactions between components of the packaging material & 4.8 \\
\hline & and the product Maintaining the quantity and quality of content & 4.6 \\
\hline & Safety in use (no defects like sharp edges) & 4.6 \\
\hline & The presence of security against unauthorized opening & 4.4 \\
\hline & $\begin{array}{l}\text { Presence of information affecting the safety of the user (i.e., the } \\
\text { date of minimum durability, warning about allergens) }\end{array}$ & 4.4 \\
\hline & The presence of first opening protection & 4.2 \\
\hline & Safety while handling (e.g., when moving, stacking) & 4.0 \\
\hline \multirow{4}{*}{ 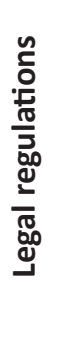 } & $\begin{array}{l}\text { Meeting the requirements of legislation, e.g., guarantee of the } \\
\text { product integrity }\end{array}$ & 4.1 \\
\hline & Information of adherence to regulations related to packaging and & 4.1 \\
\hline & packaged product & 3.7 \\
\hline & $\begin{array}{l}\text { Information concerning the protection of consumer interests in } \\
\text { terms of safety, protection of consumer economic interests and } \\
\text { protection of environment } \\
\text { Warranty usefulness for different age groups of consumers }\end{array}$ & 3.5 \\
\hline
\end{tabular}




\begin{tabular}{|c|c|c|}
\hline \multicolumn{2}{|c|}{ Packaging features } & $\begin{array}{l}\text { Features } \\
\text { validity }\end{array}$ \\
\hline \multirow{8}{*}{ 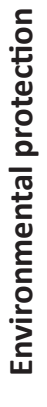 } & The use of biodegradable materials & 3.6 \\
\hline & Minimized weight of packaging & 3.6 \\
\hline & Information on how to deal with the packaging after the utility & 3.5 \\
\hline & Ease of recycling packaging & 3.3 \\
\hline & The use of recycled materials & 3.3 \\
\hline & Homogeneity of the packaging material used in the manufacture & 3.25 \\
\hline & of the packaging & 3.2 \\
\hline & $\begin{array}{l}\text { Type of packaging material from the point of load on the } \\
\text { environment }\end{array}$ & \\
\hline
\end{tabular}

Analysis of the research results on the hierarchy of the packaging features showed that among the needs and demands of consumers concerning lifestyles, the most important characteristics of food packaging is protection of the quantity and quality of content under different conditions of use and convenience of use. Indeed, these features have obtained the highest average rate of the important factor, leveling out at between 4.1-4.2 points. In the group of average validity, the following features were indicated: packaging/labels informatively, aesthetics, the variety of packaging shape and form, packaging resistance on exposures, price and variety of packaging materials (for example plastics, paper, steel, etc.). The related validity scores were found to be ranging from 3.2 to 3.9 pts.

In the group of features that increase added value for consumers, indicated as important characteristics were: additional security guarantees in packaging, the variety of shapes and volume of packaging (3.8 pts.) and its weight and design ( $3.7 \mathrm{pts}$ ). As an additional packaging characteristic, the respondents also pointed out the use of packing draining indicators and the material transparency (3.6 pts.). The lowest validity in this group of needs was attributed to product information positioning and advertising. Evaluated characteristics obtained results of the validity in the range of 2.6 to 2.9 pts.

Results were reported in Table 3, their analysis showed that, between all food packaging safety characteristics, the most important feature for consumers was the absence of chemical interaction between packaging material and the product ( $4.8 \mathrm{pts}$ ). High scores ( $4.6 \mathrm{pts}$.) were also obtained by quality of content and safety in use. Other important features were found in: the clearness through which important information is given to consumers with regard to the food contained and package used; and the presence of securities against unauthorized opening were given due attention. In the 
group of high validity features, consumers indicated the presence of firstopening protection (4.2 pts.) and safety during handling (4.0 pts.).

Analysis of the results obtained on the validity of the characteristics of food products packaging, that consider consumer demands related to legal regulations, showed that the most important feature for the respondents was legal data requirements to packaging materials and packaged food product, as meeting the legislation requirements concerning the product integrity (4.1 pts.). Other packaging features received the validity at an average level (3.5-3.7 pts.).

Research analysis revealed that the most important consumer point of view regarding the environmental aspects was the biodegradability of packaging material, minimizing the weight and volume of packaging, (3.6 pts). The less important characteristics were the type of packaging materials and its environmental performance (3.2 pts.) and homogeneity of the material used for production of packaging (3.25 pts.). Obtained results show that respondents (consumers) do not fully understand the environmental aspects of packaging materials. They have some knowledge about biodegradability or recycling but are not aware that it has an impact on the general environmental performance of packaging.

\section{DISCUSSION}

Among the analyzed characteristics of the food packaging, taking into account the requirements of consumer-related to lifestyle, safety, added value, legal requirements and environmental protection, those resulting to be significant (with value 4 and higher). They are basic guidelines for improving food packaging taking into account the requirements and needs of consumers:

- no interactions between components of the packaging material and the product;

- maintaining the quantity and quality of content;

- safety in use;

- the presence of security against unauthorized opening;

- presence of information affecting the safety of the user;

- the presence of first opening protection;

- protection of the quantity and quality of the contents in various conditions of use;

- convenience;

- meeting the requirements of legislation;

- information of adherence to regulations related to packaging and packaged product;

- safety while handling. 
The results of the survey provided the basis for a detailed analysis of needs and requirements of consumers, in the field of food packaging. The subsequent hierarchy of importance indicates the importance of the characteristics of the packaging from the point of view of the needs of users. Summary of the results obtained in the analysis is presented in Figure 2.

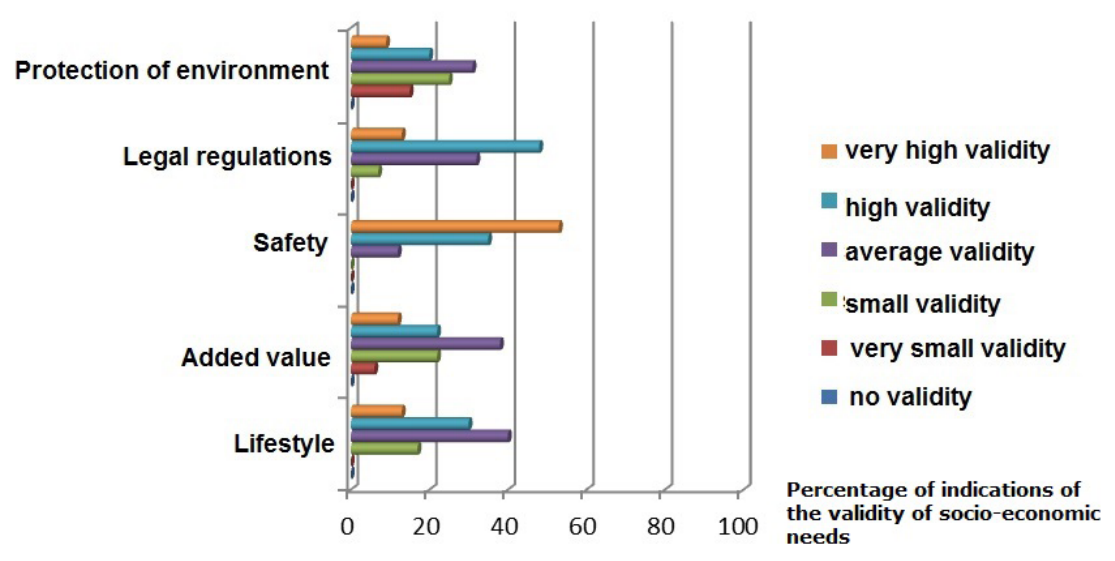

Figure 2. Importance of socio-economic consumers' needs

Analysis of the results clearly showed that among all socio-economic needs and requirements posed to food packaging, safety is the most important one for consumers. Declarations about the importance of social needs were made 200 respondents. Most of the survey participants (88\%) agree that fulfillment of requirements relating to the safety of food packaging is very important $(53 \%)$ and significant $(35 \%)$. In the group of consumers, special attention to the characteristics of packaging associated with the safety aspect was considered. Particularly, consumers with ages ranging from 26-35 years and $36-45$ years indicated this property as important. This group is dominated by women, living in cities of 250-500 thousand residents and cities of over 500 thousand residents. Results are in agreement with Jevšnik et al. (2008) because women are more aware consumers and more sensitive to food safety.

The analysis also showed that second in the hierarchy of needs/ requirements indicated by consumers was requirement associated with legal regulations. This group of needs was indicated as very important and important by $61 \%$ of all respondents. The third in order of importance for consumers was pointed to be the requirement related to lifestyle: $43 \%$ of the respondents indicated very high and high importance of this group of needs. Next in the hierarchy of needs/requirements indicated by the consumer was 
the requirement related to added value. This group of needs was indicated as very important and important by $34 \%$ of respondents. The lowest validity of the received group of needs was related to environmental protection, with a score of $29 \%$ of indications as very high and high validity, so underscoring the need for more education and information in this sense. This would allow consumers to understand that by improving the environmental quality of a package, its overall quality and functionality is improved.

Results are depicted in the graph of Figure 3.

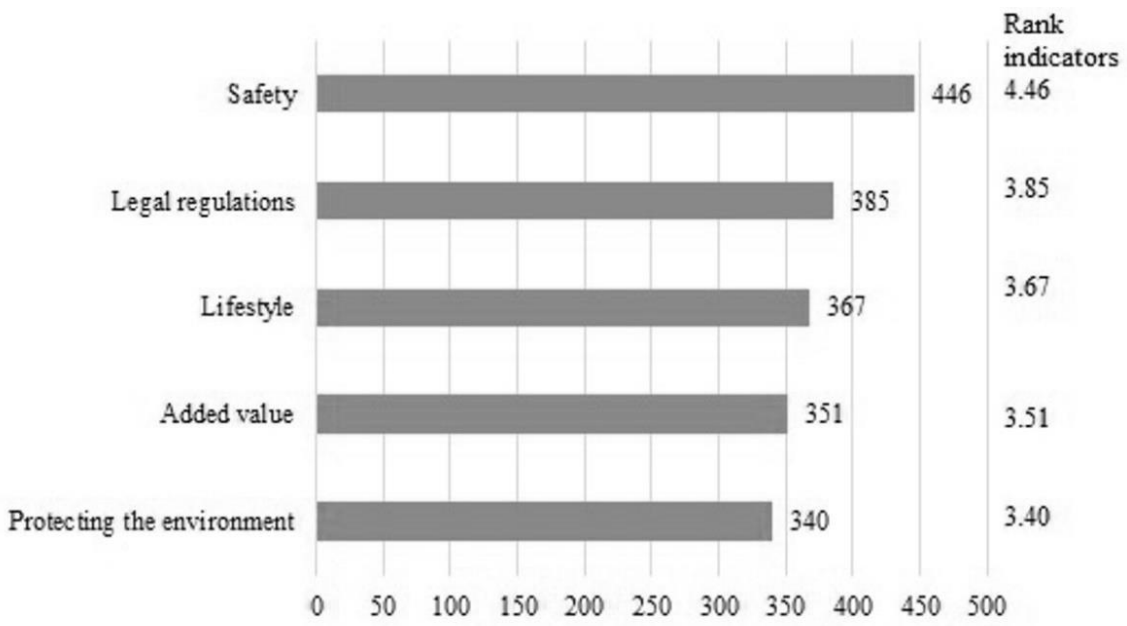

Figure 3. The hierarchy of socio-economic consumer needs

Analysis of the results indicated the order of priority of the needs from the most important ensuring safety (rank 1), meeting legal regulations (rank 2 ), needs related to lifestyle (rank 3), improving consumers' life quality through added value (rank 4), and importance of environmental protection (rank 5).

The study confirmed that both production and design of food packaging systems should be developed considering not only the technical requirements (such as barrier properties, physio-mechanic properties and chemical properties) but, also, the socio-economic and the environmental ones. In this paper, the authors proposed attributes and functions to be taken into account for improvement of food packages. Moreover, it would be desirable to consider the social needs in accordance with the hierarchy-related findings of the study. Previous studies on the topic of consumers' requirements regarding packaging were selective and concerned only lifestyle aspects. It was covered in studies by Estiri, Hasangholi, Yazdani, Nejad, and Rayer (2010), Mueller and Szolnoki 
(2010), Venter et al. (2011), van der Merwe et al. (2013), Carrillo, Fiszman, Lähteenmäki, and Varela (2014), Cholewa-Wójcik (2015); Fiszman, Carrillo, and Varela (2015), Gomez, Martn-Consuegra \& Molina (2015), added value aspects are presented in studies by Butkevivience, Stavinskiene, Rutelione, 2008; Ares \& Deliza, 2010; Ahmadi, Bahrami, Ahani (2013). The meaning of safety aspects of packaging was proven by (Wilcock, Pun, Khanona, Aung, 2004; Kawecka, 2014b; Baiardi, Puglisi, Scabroosetti, 2016). Environmental aspects importance was highlighted in the studies by Gironi \& Piemonte (2010); Svansen et al. (2010); Siracusa et al. (2014); Ingrao et al. (2015a).

Finally, it goes without saying that the fulfillment of legal requirements is mandatory because, without them, packaging would not be available on the market. Consumers are aware of this fact: this was proven by findings from this study. In the literature review, all the presented studies are fragmentary and concern only one of the aspect. This study represents a holistic approach to the topic of consumer needs and requirements.

\section{CONCLUSION}

Food packaging belongs to a group of products with a high potential for innovation. This is mainly due to the multiple, interconnected effects of functionality, ergonomics, economic and environmental advantages of the offer but, also, by changes in visual layer. Currently, to some extent, packaging responds to consumer trends related to the aging of society, change in the structure of households, change of lifestyle, increase in requirements for the convenience of products, and rising health awareness. It is reflected in differential size, the popularity of convenient packaging for convenient food, in some countries product dedicated to older people, changes of packaging materials and packaging construction dictated by the ecological consciousness of consumers. These changes have variable dynamics, and they do not always find understanding and support in the market because they are not compatible with the needs of consumers. The identification and understanding of consumer needs is a valuable source of information, which is desirable to develop guidelines for better ways to design food packaging systems. In this context, the present study was carried out to analyze the requirements for food packaging to answer consumers' needs.

Results from the analysis made it possible to determine the significance of the groups of needs/demands by consumers related to the packages. The study helped to shed light upon the social needs that predict the importance of those packaging factors. Also, the obtained results were used as the basis to investigate consumers ranking needs and requirements, in relation to food 
packaging. Assigning ranking indicators to groups of needs and requirements allowed the authors not only to create their hierarchy scale from the consumer's validity viewpoint but also to provide a database for the design of food packaging.

A further study is expected to be carried out to continue investigating consumers' needs and correlate those needs to socio-demographic consumer features. This kind of approach may lead to better adjusting design solutions in packaging for specific consumers groups, such as children, seniors and others.

The model packaging, which will stratify consumers' needs and requirements and will help to improve their life quality, should be characterized by health (safety), simplicity (reduction, convenience), identity (belonging), aesthetics (design), meaning (sustainability, intelligence). Packaging belongs to the group of products characterized by high potential in the field of implementing innovative solutions. This is mainly related to the desire to introduce solutions such as in the area of improving safety, functionality, communication and environmental protection. Identification and understanding of consumer needs is a valuable source of information necessary to develop the assumptions of packaging improvement. The components of model packaging proposed above fit into the motto of the World Packaging Organization, which says: "Better quality of life through better packaging".

\section{Acknowledgments}

The publication was financed from the funds granted to the Department of Commodity Science and Product Management at the Cracow University of Economics as a grant for the maintenance of research potential.

\section{References}

Ahani, M., Bahrami, H.R., \& Ahani, M. (2013). An investigation of visual components of packaging on food consumer behavior. Business and Economic Research, 3(2). http://doi.org/10.5296/ber.v3i2.3799

Bix, L., de la Fuente, J., Sundar, R.P., \& Lockhart, H. (2009). Packaging design and development. In K.L. Yam (Ed.), The Wiley Encyclopedia of Packaging Technology (pp. 913-920). Hoboken, NJ: John Wiley \& Sons.

Butkevičienè, V., Stravinskienè, J., \& Rūtelionienè, A. (2008). Impact of consumer package communication on consumer decision making process. Engineering Economics, 1(56), 57-63.

Capitanio, F., Coppola, A., \& Pascucci, S. (2009). Indications for drivers of innovation in the food sector. British Food Journal, 111(8), 820-838. http://doi.org/10.1108/00070700910980946 
Carrillo, E., Fiszman, S., Lähteenmäki, L., \& Varela, P. (2014). Consumers' perception of symbols and health claims as health-related label messages. A cross-cultural study. Food Research International, 62, 653661. http://doi.org/10.1016/j.foodres.2014.04.028

Cholewa-Wójcik, A. (2014). Usefulness verification of the ABCD-Suzuki method in order to analyses the consumer's needs and requirements concerning cosmetics product packaging. In J. Lewandowski, A. Walaszczyk, \& I. Jałmużna (Eds.), Product and Packaging. Contemporary Challenges (pp. 65-79). Łódź: Politechnika Łódzka Press.

Cholewa-Wójcik, A. (2015). The influence of the consumer's requirements and needs on the process of food packaging designing. In A. CholewaWójcik \& A. Kawecka (Eds.), Food Product Quality and Packaging. Current State and Challenges (pp. 7-16). Celje: University of Maribor Press.

Coles, R., \& Kirwan, M.J. (2011). Food and Beverage Packaging Technology. Chichester: Wiley-Blackwell.

Conte, A., Cappelletti, G., Nicoletti, G., Russo, C., \& Nobile, M.D. (2015). Environmental implications of food loss probability in packaging design. Food Research International, 78, 11-17. http://doi.org/10.1016/j. foodres.2015.11.015

Dąbrowska, A., Janoś-Kresło, M., Słaby, T., \& Witek, J. (2013). Niedobory Konsumpcji w Polskich Gospodarstwach Domowych. Warszawa: Oficyna Wydawnicza Szkoły Głównej Handlowej w Warszawie.

Estiri, M., Hasangholi, T., Yazdani, H., Nejad, H., \& Rayej, H. (2010). Food products consumer behaviors: The role of packaging elements. Journal of Applied Sciences, 10(7), 535-543. http://doi.org/10.3923/ jas.2010.535.543

Fiszman, S., Carrillo, E., \& Varela, P. (2015). Consumer perception of carriers of a satiating compound. Influence of front-of-package images and weight loss-related information. Food Research International, 78, 88-95. http:// doi.org/10.1016/j.foodres.2015.11.003

Gironi, F., \& Piemonte, V. (2010). Life cycle assessment of polylactic acid and polyethylene terephthalate bottles for drinking water. Environmental Progress \& Sustainable Energy, 30(3), 459-468. http://doi.org/10.1002/ ep.10490

Gómez, M., Martín-Consuegra, D., \& Molina, A. (2015). The importance of packaging in purchase and usage behaviour. International Journal of Consumer Studies, 39(3), 203-211. http://doi.org/10.1111/ijcs.12168

Gutkowska, K., Kowalczuk, I., Sajdakowska, M., Żakowska-Biemans, S., Kozłowska, A., \& Olewnik-Mikołajewska, A. (2014). Postawy konsumentów wobec innowacji na rynku żywności. Handel Wewnętrzny, 4(351), 80-93.

Ingrao, C., Giudice, A.L., Bacenetti, J., Khaneghah, A.M., Sant'Ana, A.S., Rana, R., \& Siracusa, V. (2015). Foamy polystyrene trays for fresh-meat packaging: Life-cycle inventory data collection and environmental impact assessment. Food Research International, 76, 418-426. http:// doi.org/10.1016/j.foodres.2015.07.028 
Ingrao, C., Tricase, C., Cholewa-Wójcik, A., Kawecka, A., Rana, R., \& Siracusa, V. (2015b). Polylactic acid trays for fresh-food packaging: A Carbon Footprint assessment. Science of the Total Environment, 537, 385-398. http://doi.org/10.1016/j.scitotenv.2015.08.023

Irvine, P.A. (2008). Enabling Future Packaging Innovation Through New Materials. 3rd International Microsystems, Packaging, Assembly \& Circuits Technology Conference. Taiwan: IEEE.

Jevšnik, M., Hlebec, V., \& Raspor, P. (2008). Consumers' awareness of food safety from shopping to eating. Food Control, 19(8), 737-745. http://doi. org/10.1016/j.foodcont.2007.07.017

Kawecka, A. (2014a). Packaging design in respect to environmental issues. In J. Lewandowski, A. Walaszczyk \& I. Jałmużna (Eds.), Product and Packaging. Contemporary Challenges (pp. 65-79). Łódź: Politechnika Łódzka Press.

Kawecka, A. (2014b). Czynniki Determinujq̨ce Bezpieczeństwo Opakowań Przeznaczonych do Kontaktu z Żywnościq̨. Kraków: Wydawnictwo Uniwersytetu Ekonomicznego.

Kawecka, A. (2015). Market behaviour of young consumers and their attitudes towards food packaging in the market offer. In M. Gębarowski \& T. Hermaniuk (Eds.), Food Products Marketing. Concepts and Research (pp. 95-106). Celje: University of Maribor Press.

Labbe, D., Pineau, N., \& Martin, N. (2013). Food expected naturalness: Impact of visual, tactile and auditory packaging material properties and role of perceptual interactions. Food Quality and Preference, 27(2), 170-178. http://doi.org/10.1016/j.foodqual.2012.06.009

Lisińska-Kuśnierz, M. (2011). Oczekiwania konsumentów dotyczące opakowań a realizacja ich potrzeb społeczno-ekonomicznych. Zeszyty Naukowe Uniwersytetu Ekonomicznego w Krakowie, 874, 89-100.

Lisińska-Kuśnierz, M. (2014). Food packaging as non-satisfactory communication instrument in opinion of consumers. In A. CholewaWójcik \& A. Kawecka (Eds.), Commodity Science in Research and Practice - Innovations in product development and packaging (pp. 141-157). Cracow: Polish Society of Commodity Science.

Lisińska-Kuśnierz, M., \& Kabaja, B. (2018). The convenience of use and informative functions of the bag-in-box packaging systems for NFC juices. Polish Journal of Commodity Science, 3(56), 23-34.

Lisińska-Kuśnierz, M., \& Ucherek, M. (2011). Essence of holistic angle on development of consumer behaviour by packaging. Polish Journal of Commodity Science, 4(28), 66-72.

Loizou, E., Michailidis, A., \& Chatzitheodoridis, F. (2013). Investigating the drivers that influence the adoption of differentiated food products. British Food Journal, 115(7), 917-935. http://doi.org/10.1108/bfj-042010-0068

Merwe, D.V., Viljoen, S., Beer, H.D., Bosman, M., \& Kempen, E. (2013). Consumers experiences of cold chain food packaging: A qualitative 
study among women in South Africa. International Journal of Consumer Studies, 37(6), 650-657. http://doi.org/10.1111/ijcs.12052

Mueller, S., \& Szolnoki, G. (2010). The relative influence of packaging, labelling, branding and sensory attributes on liking and purchase intent: Consumers differ in their responsiveness. Food Quality and Preference, 21(7), 774-783. http://doi.org/10.1016/j.foodqual.2010.07.011

Ng, M., Chaya, C., \& Hort, J. (2013). The influence of sensory and packaging cues on both liking and emotional, abstract and functional conceptualisations. Food Quality and Preference, 29(2), 146-156. http://doi.org/10.1016/j. foodqual.2013.03.006

Emblem, A., \& Emblem, H. (2012). Packaging Technology Fundamentals, Materials and Processes. Cambridge: Woodhead Pub.

Position Paper - Market Trends and Developments (n.d.). Retrieved 22 February, 2016, from http://www.worldpackaging.org/i4a/doclibrary/ getfile.cfm?doc_id=14

Prognoza gospodarstw domowych na lata 2016-2050. (2016). Warszawa: Główny Urząd Statystyczny, Departament Badań Demograficznych i Rynku Pracy.

Raport na temat wpływu zmian demograficznych i starzenia się społeczeństwa. (2016). Warszawa: Główny Urząd Statystyczny, Departament Badań Demograficznych i Rynku Pracy.

Rebollar, R., Lidón, I., Serrano, A., Martín, J., \& Fernández, M.J. (2012). Influence of chewing gum packaging design on consumer expectation and willingness to buy. An analysis of functional, sensory and experience attributes. Food Quality and Preference, 24(1), 162-170. http://doi. org/10.1016/j.foodqual.2011.10.011

Rudnicki, L. (2012). Zachowania Konsumentów na Rynku. Warszawa: Polskie Wydawnictwo Ekonomiczne.

Siracusa, V., Ingrao, C., Giudice, A.L., Mbohwa, C., \& Rosa, M.D. (2014). Environmental assessment of a multilayer polymer bag for food packaging and preservation: An LCA approach. Food Research International, 62, 151-161. http://doi.org/10.1016/j.foodres.2014.02.010

Svanes, E., Vold, M., Møller, H., Pettersen, M.K., Larsen, H., \& Hanssen, O.J. (2010). Sustainable packaging design: A holistic methodology for packaging design. Packaging Technology and Science, 23(3), 161-175. http://doi.org/10.1002/pts.887

Sykut, B., Kowalik, K., \& Droździel P. (2013). Współczesne opakowania dla przemysłu żywnościowego. Nauki Inżynierskie i Technologie, 3(10), 114-121.

Tarczyńska, S. (2013). Projektowanie żywności wygodnej z wykorzystaniem metody QFD. Żywność. Nauka. Technologia. Jakość, 3(88), 187-199.

The Future of Global Packaging to 2018. Market Reports (Rep.). (2013). Surrey: Smithers Pira.

Top 10 Design Trends for 2011. (2012, July 15). Retrieved from https:// extremehowto.com/top-10-design-trends-for-2011-2/ 
Solomon, M., Bamossy, G., \& Askegaard, S. (2002). Consumer Behavior: A European Perspective. Harlow: Financial Times Prentice Hall.

Venter, K., Merwe, D.V., Beer, H.D., Kempen, E., \& Bosman, M. (2010). Consumers perceptions of food packaging: An exploratory investigation in Potchefstroom, South Africa. International Journal of Consumer Studies, 35(3), 273-281. http://doi.org/10.1111/j.1470-6431.2010.00936.x

Yam, K.L. (2009). Socioeconomic driving forces of food packaging. In K.L. Yam (Ed.), The Wiley Encyclopedia of Packaging Technology (pp. 859-866). Hoboken: NJ: John Wiley \& Sons.

Zalega, T. (2007). Gospodarstwo domowe jako podmiot konsumpcji. Studia i Materiały. Wydział Zarzq̨dzania Uniwersytetu Warszawskiego, 1, 7-24.

\begin{abstract}
Abstrakt
Trendy w branży opakowań żywności odzwierciedlajq zidentyfikowane potrzeby i wymagania konsumentów, które przedsiębiorcy powinni spełniać aby zaspokoić zmieniające się wymagania konsumentów, a także aby osiagnać i utrzymać przewagę konkurencyjnq dzięki innowacjom. W grupie potrzeb społeczno-ekonomicznych najistotniejsze z nich to: zmiany stylu życia, poprawa jakości życia poprzez wartość dodanq oferowanq konsumentom za pośrednictwem zapakowanych produktów, bezpieczeństwo produktów opakowanych i ochronę środowiska. Głównym celem przeprowadzonych badań była ocena ważności wymagań dotyczacych pakowania żywności pod kq̨em zaspokojenia potrzeb konsumentów. Głównym wkładem pracy jest opracowanie hierarchii ważności potrzeb i wymaga, która stanowi podstawę dla rozwiqzań i strategii majq̨cych na celu poprawę jakości życia konsumenta. Analiza wyników wykazała, że wśród wszystkich społeczno-ekonomicznych potrzeb i wymagań zwiqzanych z pakowaniem żywności bezpieczeństwo jest najbardziej krytycznq potrzebq konsumentów. Istotne sq także inne właściwości i cechy opakowania, takie jak wygoda i spełnienie wymagań prawnych. Proponowane opakowanie modelowe, które zaspokoi potrzeby i wymagania konsumentów i przyczyni się do poprawy ich jakości życia, powinno charakteryzować się: bezpieczeństwem zdrowotnym, prostotq, tożsamościq i estetykq. Branża opakowaniowa to branża uważana za majqca duży potencjał w zakresie stosowania innowacyjnych rozwiqzań. Jest to zwiqzane głównie z chęciq wprowadzania rozwiqzań w obszarach poprawy bezpieczeństwa, funkcjonalności, komunikacji i ochrony środowiska. Identyfikacja i zrozumienie potrzeb konsumentów jest cennym źródłem informacji przydatnych przy opracowywaniu ulepszeń. Proponowane komponenty opakowań modelowych sq zgodne z mottem Światowej Organizacji Opakowań, która brzmi: "Lepsza jakość życia dzięki lepszemu opakowaniu".
\end{abstract}

Słowa kluczowe: opakowania do żywności, socjoekonomiczne potrzeby, wytyczne, innowacje opakowań do żywności. 


\section{Biographical notes}

Agnieszka Cholewa-Wójcik - doctor of economic sciences in the field of Commodity Science. Research interests include kinetics of changes in the quality of packaging materials, durability of packed food products and innovativeness in unit packaging. She is a member of the Polish Commodity Science Society and a member of the Polish Logistic Technology Platform and an expert in the field of packaging and storage of goods. Agnieszka CholewaWójcik is also the author of expert opinions and opinions for enterprises and for State Bodies. She works with national and international companies and is a member of the software and technical board of the packaging industry.

Agnieszka Kawecka - an employee of the Faculty of Commodity Science and Product Management since 2006, Ph.D. in economics in the field of commodity science. Research interests concentrating in particular on the subject of packaging safety, safety systems in the production and marketing of packaging and packed products, food products logistics and industrial and environmental aspects related to packaging and the functioning of supply chains. Appraisal of the Polish Commodity Science Society in the field of packaging and storage of goods. Cooperates as an expert with Chamber of Industry and Commerce in Krakow, the Polish Agency for Enterprise Development.

Carlo Ingrao obtained an M.Sc. Degree in Environment and Land Management Engineering at the University of Catania (Italy), in 2007. Later, in 2012, he was titled as Ph.D. in Geotechnical Engineering at University of Catania. Since 2013, he has carried out research under several collaboration contracts and scholarships, mainly at the Universities of Catania and Foggia (Italy). Moreover, in the year 2013-2014, he was a postdoctoral fellow at the University of Foggia for collaboration to the research activity provided by the 7FP European project 'Strategic and Technological Advancement in Research on Agroenergy' (STAR*Agroenergy). His research activities and interests are mainly focused upon the development of energy, environmental and economic assessments in the fields of industrial and environmental engineering; commodity sciences; buildings; biomass and bioenergy; agriculture and food production; and food packaging. Within those themes, since 2013 he has authored and co-authored more than fifty publications in international journals, book chapters and conference proceedings, most of them being indexed by Scopus and/or WoS. 
Siracusa Valentina received her degree in Industrial Chemistry at the University of Catania (Italy. She completed her Ph.D. and post-PhD study working on the synthesis and characterization of innovative polyesters, used in the engineering field. After a period as lectures for "Chemistry and Materials" for Engineering, since 2006 she has been Associate Professor on Chemistry for Engineering at Catania University. She collaborates on several research projects, both for academic and industrial interest, on topics such as recycling, ambient, food packaging, graphene. She collaborates with national and international research groups on biopolymers used in the field of food packaging, for modified atmosphere packaging of fresh foods, with also Life Cycle Assessment study (with SimaPro8 software). She is the author of more than 70 papers in high impact factor scientific journals, she is the author of several book chapters for Wiley, Springer, Elsevier, she is the author of articles for a special Module of Elsevier Encyclopedia and she is guest editor of International Journals. Her research interests include synthesis and full characterization of biodegradable and bio-based polymers; gas barrier behavior; Life Cycle Assessment (LCA) study of polymers for food packaging applications; thermal and photo degradation behavior of packaging materials analyzed during food shelf-life study. 